\title{
Net-zero emission vehicles shift and equitable ownership in low-income households and communities: why responsible and circularity business models are essential
}

\author{
Nana O. Bonsu ${ }^{1}$ \\ Received: 26 November 2020 / Accepted: 28 January 2021 \\ (c) The Author(s) $2021 \quad$ OPEN
}

\begin{abstract}
The UK Plan for a Green Industrial Revolution aims to ban petrol and diesel cars by 2030 and transition to electric vehicles (EVs). Current business models for EV ownership and the transition to net-net zero emissions are not working for households in the lowest income brackets. However, low-income communities bear the brunt of environmental and health illnesses from transport air pollution caused by those living in relatively more affluent areas. Importantly, achieving equitable EV ownership amongst low-and middle-income households and driving policy goals towards environmental injustice of air pollution and net-zero emissions would require responsible and circular business models. Such consumerfocused business models address an EV subscription via low-income household tax rebates, an EV battery value-chain circularity, locally-driven new battery technological development, including EV manufacturing tax rebates and socially innovative mechanisms. This brief communication emphasises that consumer-led business models following net-zero emission vehicles shift and decisions must ensure positive-sum outcomes. And must focus not only on profits and competitiveness but also on people, planet, prosperity and partnership co-benefits.
\end{abstract}

\section{Introduction}

In the last couple of years, ambient air pollution and climate change concerns have reinforced the UK's ambitious policy to transition to electric vehicles (EVs). As a result, the UK government's recent announcement that sales of internal combustion engine vehicles/petrol and diesel vehicles (ICE) will end by 2030 has already directed the public mind towards EVs. However, many barriers to EV uptake persist despite the government's ambitious target to banish ICE and decarbonise the transport sector by 2030, e.g., point 4: accelerating the shift to zero-emission vehicles in the Ten Point Plan for a Green Industrial Revolution.

A recent study that interviewed thirty multi-stakeholder groups shows the challenges in delivering equitable EV ownership in low-income households. This study interviewed multi-stakeholder EV groups and actors from local authorities, vehicle manufacturers, electric vehicles (EVs) fleet operators, policy think tanks, non-profit organisations, EV policy shapers, academics, and energy and raw mineral companies [1]. The interview scripts were transcribed verbatim, and transcripts were analysed with the aid of NVivo 12 software.

The study revealed that charging infrastructure is not the only problem to mainstreaming EVs in the UK. However, the lack of innovative consumer experience with $\mathrm{EV}$ technologies or a transition plan from petrol and diesel cars (ICE) to EVs, and the need to bridge the urban-rural charging infrastructure gap, improve EV incentives and solve the EV range anxiety (e.g., affording a 200-300 mile range EV), as well as investment in disadvantaged and low-income communities, are

Nana O. Bonsu, n.obonsu@bham.ac.uk| 'Lloyds Banking Group Centre for Responsible Business, Birmingham Business School, University of Birmingham, Birmingham B15 2TT, UK.

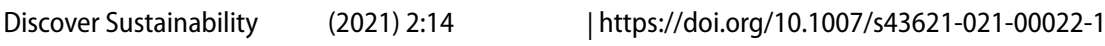


all challenges in the transition to net-zero emission vehicles. Similarly, a recent set of figures from the Society of Motor Manufacturers and Traders (SMMT) in the UK shows that registrations for pure EVs/ultra-low emission vehicles (ULEVs) in the first 9 months of 2020 were up to $127 \%$ compared to 2019 [2].

Yet, this growing market comprises higher-income consumers, with over half of EV owners still primarily concentrated among the top $20 \%$ wealthiest income earners [2]. Most private EV owners are currently middle-aged, male, well-educated, affluent, and live in urban areas with households containing two or more cars and the ability to charge at home [3]. Indeed, those in the lowest two income brackets made up just 4\% of EV owners from 2015 to 2017 [2]. Such a disparity amongst $\mathrm{EV}$ ownership in the UK emphasises the rich vs poor aspect of EV acceptance and the affordability gap in decarbonising the transport sector revealed in the study. Regrettably, the income disparity in EV ownership is even more salient given that minority and low-income postcodes bear the brunt of environmental and health illnesses, such as air pollution from road transport [4,5] and its interplay with socio-environmental determinants of health. Demographic and socio-economic analyses have indicated that, in Britain, low-income households may be disproportionately represented in areas with the highest concentrations of nitrogen dioxide $\left(\mathrm{NO}_{2}\right)$ pollution on average than those living in affluent neighbourhoods [6]. Thus, social inequality and environmental injustice are present [6]. Furthermore, road transport pollution within poor areas is caused by those living in relatively more affluent areas, compounding environmental injustice [7].

Bold efforts, including innovative, transformative responsible business models to decarbonise the transport sector and close the EV ownership equity gap, are overdue. Hence, the Green Industrial Revolution Plan proposed green paper due in 2021 on the UK's post-EU emissions regulations presents an excellent opportunity to address this collision of equity and sustainability injustices (i.e. economic, social and environmental injustices) experienced within low-income communities.

Informed by the study, this brief communication explores potential 'responsible and circular business models' useful to guide equitable EV ownership vis-à-vis, EV cost and knowledge gaps towards net-zero emissions and distributive justice. The subsequent sections provide brief insights into EV technology and responsible business models useful for managing public policy gaps in achieving equitable EV ownership in low-income households while tackling economic, environmental and health injustices within postcodes.

\subsection{Low-income EV ownership versus the EV technology interplay}

Some of the barriers affecting prospective EV customers and uptake are understanding EV technology, lack of incentives and engagement with EV dealers and manufacturers [8]. For example, there is a lack of public awareness of how EVs work and their battery technology being integral in this shift. An LA EV policy lead highlighted that "in terms of public education, there isn't anything yet we're doing for the public", which inhibits consumer EV uptake "because of fear of the unknown, uncertainty, and consumers' do not understand the EV technologies properly". Thus, a key measure in the transition to EVs is consumers' role in understanding $\mathrm{EV}$ technology, i.e., where battery technology currently remains the heartbeat powering EVs, determining about one-third of EVs high-cost, the resale value and net-zero futures [9].

First, as insight into contemporary EV models, studies show that EVs powered by lithium-ion batteries (LIBs) account for one-third or approximately $40 \%$ of the entire value-added share of an EV [10]. Thus, the added battery price resulting from its design, manufacturing process, and machinery required, including high-cost critical raw minerals such as cobalt and nickel, makes consumers' upfront cost to purchase EVs thousands of dollars, pounds or euros more expensive than buying a similar ICE model.

In recent years, LIB cell prices have decreased from $\$ 290 / \mathrm{kWh}$ in 2014 to $\$ 110 / \mathrm{kWh}$ in 2020 (Fig. 1), yet LIBs raw material risk looms [11]. However, EVs reaching production cost parity with ICE vehicles are indeterminate and may take some time [12]. And LIB price uncertainties could arise due to unforeseen global supply and value chain enablers and shocks arising from LIB manufacturing and critical raw mineral sourcing, e.g., geopolitical conflicts and tensions with China (having a global grip on EV LIB raw material sourcing, cell and module manufacturing, including pack assembly), land-use conflicts, e.g. mining ecological impacts versus local communities resistance, ethical and political instability and wars in unstable mineral-rich countries such as the Democratic Republic Congo and the impact of pandemics on supply chains.

Although LIB prices are decreasing and the UK government has taken positive steps in the form of $£ 582$ million in grant funding to help make EVs cheaper and $£ 500$ million available for EV battery production, this may still not be enough to address equitable EV ownership. Likewise, the collision of economic, social, health and environmental injustices experienced within low-income communities and households. Consequently, more investment and innovative business models directed at stimulating EV uptake on a large scale amongst low-income earners are urgently needed, e.g., business models useful to offset EV battery value share and financial burden bestowed on low-income households. 
Fig. 1 Lithium-ion cell price $\$ / k W h$, Source: Benchmark mineral intelligence

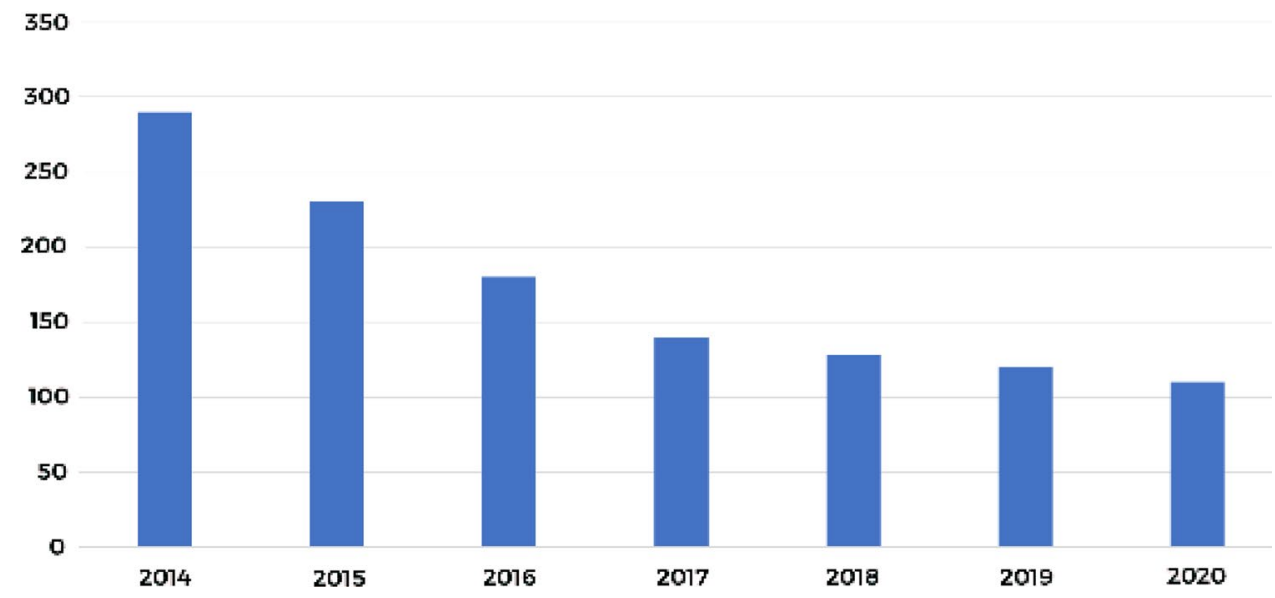

Unlike a diesel or petrol vehicle, an EV battery (LIB), similar to smartphone batteries, repeatedly undergoes cycles of discharging when driving and charging during plug-in, affecting the amount of charge the battery can hold [13]. Many studies show that the EV battery capacity fades over time, making it unsuitable to meet EV performance when the original power falls below $70-80 \%[14,15]$. However, other studies show that EV batteries continue to meet drivers' daily travel needs well beyond a capacity fade of $80 \%$ of the remaining energy storage capacity [16]. As a significant relief to consumers following EV costs and battery retirement thresholds, auto manufacturers usually warrant an EV battery for a set time. For example, mainstream EV manufacturers—-such as BMW i3, Nissan and Tesla-offer a battery warranty for 8 years or 100,000 miles on some EV models.

Therefore, looking to ensure excellence in environmental injustices and EV ownership amongst those in the lowest income brackets may follow innovative ways of thinking and adopting consumer-focused business models and typologies towards distributive justice outcomes. Developing such business models requires a focus on inclusivity, a mix of policy instruments and good governance: encouraging multi-stakeholder decision-making processes, financial incentives, engaging local authorities, public health experts, auto manufacturers and traders, charging infrastructure businesses, community groups, minority groups, civil societies, EV experts, academics, companies, retailers and financial organisations, etc. to jointly develop bespoke locally-driven EV transition plans, policies, and programmes. Such consumer-focused business models are urgently needed to tackle technological equity, injustices and environmental emission emergencies within deprived communities and low-income households.

\section{Overcoming such injustices}

Below highlights some innovative business models that may contribute to EV consumer-led and circular business models towards equitable EV ownership, tackling sustainability injustices and net-zero emission targets.

\subsection{Integrated net-zero emission vehicle subscription business model}

The design of EV incentives is vital to spurring the EV market, and the timing is a critical factor in its effectiveness [8]. Additionally, financial incentives help reduce the point-of-sale purchase price of an EV and are more attractive to consumers than incentives received later in the future [17]. The study revealed that the "current incentives for ULEVs should be made more attractive, by expanding and offering low-income consumers tax relief/taxation incentives on EVs and exchanging ICE vehicles on the Go Ultra Low scheme with auto dealers".

Presently, in the UK, ULEVs are eligible for tax benefits if purchased through a salary sacrifice agreement between an employer and employee. In this scheme, the employee's cash remuneration is reduced for an equivalent benefit in kind [18]. However, given current EV prices and tough economic times, such a salary sacrifice scheme and monthly deductions are likely to benefit wealthy earners. Thus, in the design of responsible business models accelerating the shift to zeroemission vehicles, key trade-offs and synergies between policy goals_especially 'strategic government zero-emission policy goals' versus ' affordability and public acceptance' —must be explored. 
Given this, responsible business models must aim to create positive-sum outcomes, focusing not only on businesses profits and the UK competitiveness but also on winning for people, planet and prosperity. Importantly, policy trade-offs must strive to create a virtuous cycle towards the UN's Sustainable Development Goals (SDGs) and potential harness synergies vis-a-vis the social, economic, political, ethical, environmental and technological factors influencing the system change for net-zero emission vehicles [9].

From a pure EV ownership cost and sustainability public policy perspective, the battery subscription circular business model is attractive. Not only does a subscription business model deliver a higher return on acquisition costs by increasing the overall customer lifetime value [19]. It will also allow businesses and policy-makers to connect with consumers and share knowledge on net-zero emission policy and harness sustainability investment. Particularly, to create sound national public policy frameworks based on pro-poor development strategies (SDG 1), while substantially reducing the number of deaths and illnesses from air pollution (SDG 3). Likewise, ensure access to affordable cleaner energy (SDG 7), tackling reduced inequalities (SDG 10) and ensuring sustainable cities and communities (SDG 11).

National government-led business models must allow manufacturers, dealers, and public outreach campaigns to expand EVs' appeal and awareness to a larger consumer market. Thus, like subscriptions for Amazon Prime and Netflix, an integrated net-zero emission vehicle subscription model will help cut the upfront cost for many low-income consumers to be forced to buy ULEV by 2030 and beyond. Following this decoupling EV purchase business model under a revision of the current Tax benefits for ULEV, a robust, innovative consumer-led battery subscription model within distributive justice lens in sustainable transportation, could ensure low-income families/households paying only the vehicle value price share minus the cost of the battery. Though it sounds controversial, the EV battery (dependent on LIB production cell prices, future cheaper battery technology and $\mathrm{EV}$ parity cost to petrol and diesel vehicles) can be financed or absorbed from low-income consumers' national income tax, and as an early adoption incentive. A subscription model can extend within a warranty period,-and unlocking the sustainability case for LIBs' raw materials recycling or second-life use with a low-carbon grid in mind, i.e., when LIB power falls below $70-80 \%$ of their original capacity. Thus, helping the government meet another of its Green Industrial Revolution Plan objectives.

As a positive-sum outcome, an integrated net-zero emission vehicle subscription model and arrangements between the governments, financial institutions, auto manufacturers and traders, including other relevant actors within the value chain, must aim to:

- Ensure consumers from low-income households and communities within a certain period can soon subscribe to eligible ULEV plans. For example, considering current EV prices and battery interplay [11], low-income consumers within a specific income threshold can make a payment arrangement towards $60 \%$ of the vehicle value rather than waiting until 2030. And enjoy flexible one-third or $40 \%$ LIB tax rebates as early adoption via their national income tax reductions at the point of sale. Such a business model could be useful until cheaper EV battery technology becomes mainstream or low-cost LIBs impact price parity with ICE. Given this, actors involved (government, auto manufacturers, dealers, banks/financial institutions, consumers, etc.) can all win by creating win-win opportunities and actions for sustainability-i.e. a win for the people, planet, prosperity, profit, and partnership towards the 2030 Agenda and beyond. As a responsible business model, a subscription model can be useful to stimulate net-zero emissions towards a low-carbon grid, i.e., degraded EV batteries used as stationary energy storage to offer renewable energy grid services [21].

- Offer low-income consumers the opportunity and affordability to drive desired long-range priced EV models (e.g., executive saloons and large SUV) much sooner than 2030. Therefore, address consumers' EV fear of the 'unknown', i.e. accounting for range anxiety and options to drive 200-300 mile range ULEV and specific brands. Such an innovative model supported by investments and incentives will help keep the National Grid projected $36 \mathrm{~m}$ EVs on the UK roads by 2040 alive.

- Address insurance coverage, servicing and maintenance, including full disclosure of hidden taxes and charges linking to battery replacement/upgrades or repurposing schemes.

- In tandem with a coherent roll-out of on-street and home off-street charging infrastructure, including residential charging, this integrated subscription business model could consider consumer ULEV use of charging infrastructures countrywide, e.g., via a charging card.

- EVs' sustainability benefits, e.g., reduced air pollution emissions, annual reduced consumer costs of energy/fuel, comfort to drive, and decreased service and maintenance compared to ICE vehicles, should be promoted. 
Inevitably, the majority of low-income households are more likely to purchase second-hand/used EV vehicles. Therefore,

- The current 100,000 miles battery warranty practices do not make second-hand ULEVs with 'near degraded or end of first-life' batteries an economically viable and sustainable choice-unless an aftermarket extended warranty on a used LIB for low-income households can be ensured from auto dealers and all relevant actors.

- A 'consumer clause' to guarantee and test used EV battery state-of-health/degradation before purchase to low-income consumers should be a part of any innovative consumer-led business model [9]. Indeed, such political and procedural public policy design presents an opportunity to positively impact EV battery circularity programs.

As a measure to boost ULEV purchases in the UK under this business model and towards complete battery circularity, consumers should be encouraged to take advantage of the current EV Plug-in Car Grant schemes for switching to ULEVs. To offset the high costs of batteries, these degraded EV batteries in second life are used as stationary batteries to offer grid services [20].

\subsection{Closing-the-loop: LIB upgrade and modular circular economy models}

Beyond the integrated subscription business model in spurring the EV market, governments need to consider a modularity circular business model when designing EV programs to stimulate net-zero emissions towards a low-carbon grid. A battery modularity business model is an example of a closed-loop business model where vehicle manufacturers, dealers, or registered certified businesses take ownership of repurposing and recycling batteries and provide battery replacement solutions for consumers [9]. As a measure of the low-carbon grid and 1.5-degree net-zero emissions, a circular business model ensures repurposing LIBs after their EV life (i.e., when LIB power falls below $80 \%$ of their original capacity) for use in grid storage solutions $[9,21]$.

For grid storage and net-zero emissions policy goals, $80 \%$ performance of second-life LIB is deemed good enough to power renewable energy sources from solar or wind for household energy storage applications until the end of the LIB's second life. In many ways, a modularity business model via renewable energy sources can help meet peak power demand within households and improve households' energy efficiency in the over 3.5 million fuel poverty among lowincome families in the UK whilst boosting household income [22]. However, safety is one of the most significant barriers to the nascent second-life LIB industry. Thus, business models must address legislative safety frameworks and risks such as electrocution, battery explosions, applicable codes and standards for repurposing LIBs in stationary energy and grid storage applications. Besides, without battery technological advancements as safe energy storage devices, it will be challenging to fully harness cleaner and renewable energy sources, such as wind and solar, within the built environment and the EV value chain, e.g., within households, manufacturing and decarbonising the mining sector.

This circular business model will become robust only with regulatory and marketplace frameworks, ensuring upgrading and repurposing degraded LIB cells after EV use is brought back into the supply chain. Incentives and investments are useful for spurring consumer-end acceptance-i.e., testing, recovering, replacing, repurposing, and recycling LIBs-in such a closed-loop model designed for the second-life battery marketplace. For example, the ReLiB project, including auto manufacturers and expert registered businesses such as Circular Energy Storage, can play a crucial role in improving EV battery recycling efficiency in the UK. Incentivising consumers will also signal that they have a personal responsibility for protecting the natural environment and a stake to help the climate emergency.

As a rule of thumb, a LIB upgrade and circularity business model backed with responsible business consumer legislative frameworks should ensure the following:

- Automakers and dealers commit to a consumer-focused sustainable battery plan and do not make it difficult for consumers to upgrade on a battery subscription plan.

- There is a replacement plan for the original EV battery pack to give the EV a new spark of life with more range and value for money to benefit low-income EV consumers.

Given this, an EV battery upgrade plan (with a battery warranty for a total of 100,000 miles or five or a maximum of 8 years, whichever comes first) should aim towards a circular economy design in generating new revenue and marketplaces that support a low-carbon grid. And among other things, ensure resource efficiency through raw material recovery. 
In fact, for such proposed battery upgrade business models to work properly in tandem with a subscription model, investing billions of pounds more into the UK auto sector is critical to becoming a global superpower in the EV industry. Investment measures in EV and battery technological advancement should support up new start-ups, e.g. second-life start-ups, and boost efficient local battery development, i.e. the Battery Industrialisation Centre (UKBIC) part of the Faraday Battery Challenge. Creatively, investments, including ULEV manufacturing tax breaks for local auto manufacturers, such as Jaguar Land Rover and Nissan, can also ensure the development of local affordable/cheaper EV models to increase ULEV uptake and become competitive globally. Such investment and local production recommendation could become explicit in the EV net-zero emission proposed green paper in 2021.

\subsection{Global value chain responsible and circularity business model}

The study on the UK shift to EVs reveals the importance of overcoming issues around the critical raw minerals for batteries, including battery manufacturing and supply chain risks and the negative externalities caused by mining and resource consumption in mineral-rich countries [9].

The study acknowledges that the EV value chain and low-carbon revolution will require a substantial increase in mining several essential critical raw minerals and metals, such as lithium, cobalt, manganese, nickel and copper, in the roll-out of charging infrastructure and wind turbines for EVs [9]. Thus, as part of the UK's Green Industrial Revolution Plan for transitioning to EVs and net-zero emissions, remodelling the EV industrial ecosystem and recognising values at each point of EV product life remain vital. This means a global value chain based on a responsible circular business model that addresses raw mineral extraction, manufacturing, transportation, operations, distribution, sales, use, reuse, repair, remanufacturing, recycling and innovation mechanisms, as shown in Fig. 2.

Accordingly, a careful balance of the upstream value chain and resource scarcity as part of a responsible circular business model, e.g., in the UK's Green Industrial Revolution Plan, must address the dependency on China and other non-UK and Asian countries on EV LIB raw material sourcing and cell and module manufacturing, including pack assembly and recycling [9]. In other words, address upstream environmental emissions within the global value chain, vis-à-vis the geographical unbundling economies', following production, manufacturing and resource consumption patterns.

\section{Electric Vehicle Transition \& Battery Technology Circularity Business Model}

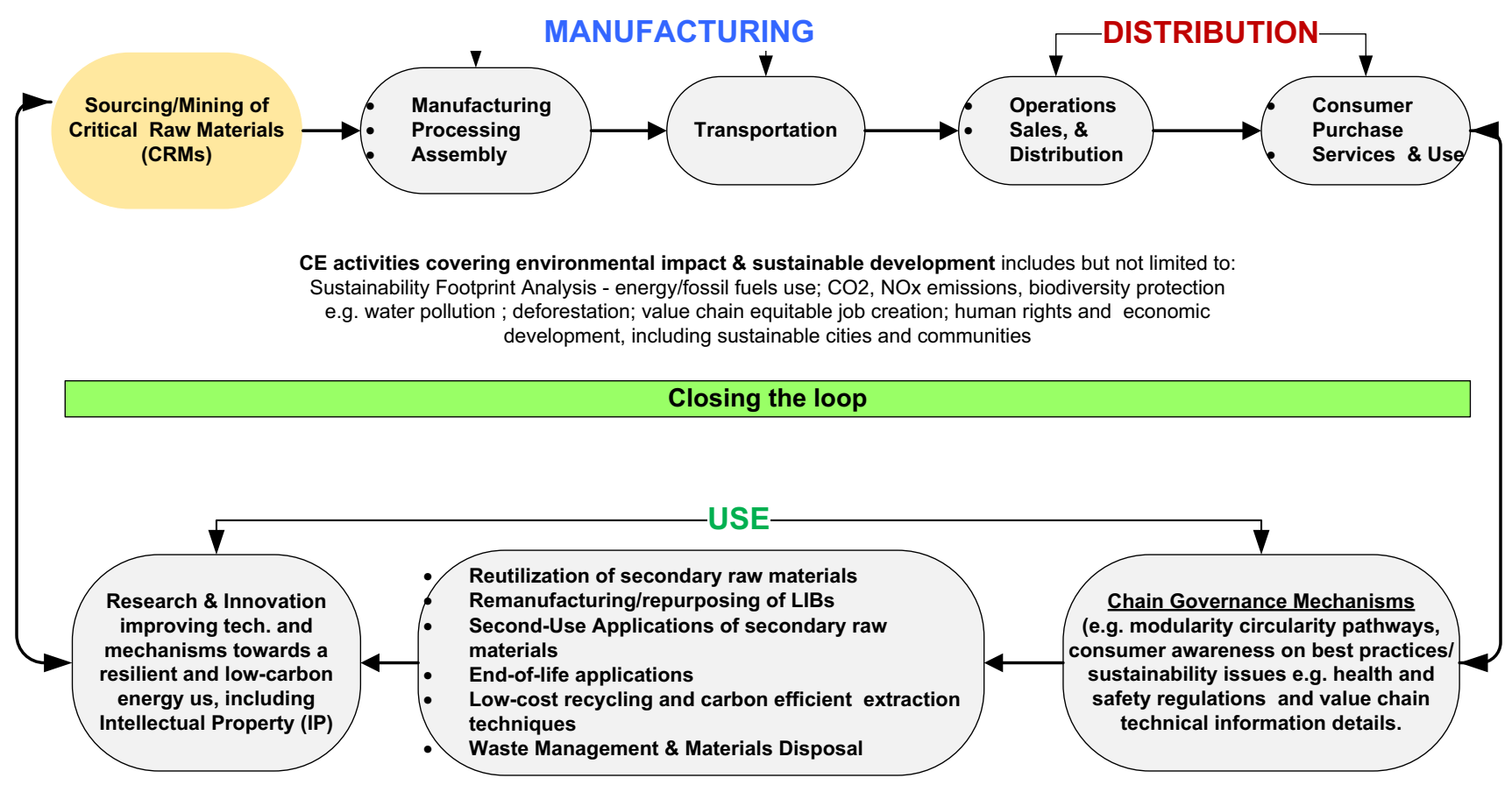

Fig. 2 The electric vehicle transition and battery circularity sustainable business model 
As shown in Fig. 2, a responsible circular business model for the EV global value chain should aim to address the following:

- Fossil fuel use, e.g., carbon dioxide $\left(\mathrm{CO}_{2}\right)$ and nitrogen oxide (NOx) emissions; resource consumption/depletion and risks; and biodiversity protection, e.g., local water pollution and water stress in sourcing raw minerals (such as lithium, nickel-manganese-cobalt cathode material for LIBs). It is essential to note that mining operations account for $11 \%$ of global energy use; hence, the mining sector also needs to be reformed to accelerate the shift to zero-emissions [23]. However, only a few world's largest mining companies (by market capitalisation) have committed to reaching net-zero emissions by 2050 or sooner. And there is no net-zero targets plan for Scope 1 and 2 (direct emissions and emissions from purchased energy) targets that support the Paris climate's goals accord.

- Value chain ethical issues addressing human rights, forced labour and economic development issues, including measures for second-life reuse or repurposing, and waste management in building sustainable cities and communities.

- Avoid a scenario where highly polluted, banned ICE vehicles will be shipped or exported to low-middle-income countries (LMICS), including resource-rich mineral countries. Notably, millions of ICE vehicles exported from Europe, the United States, and Japan to the developing world are of poor quality, contributing significantly to air pollution and hindering efforts to mitigate the effects of climate change [24].

\section{Discussion}

\subsection{Technological, regulatory and socially innovative measures}

The climate emergency and the need for net-zero emissions are still not widely known by much of the public [25]. The study reveals that current consumer education and EV business propositions "are not good enough". Therefore, to promote EVs in low-income communities and households, the subscription and circularity business models provide an opportunity for air pollution and climate emergencies, including net-zero knowledge transfer and education pathways. However, EV infrastructural investments and promotion within low-income communities must look beyond profit and aim to regenerate and socially innovate low-income communities towards sustainable development.

Perhaps an overarching approach to a socially innovative business model will provide clarity for a better public understanding of air pollution, a climate emergency and the politically framed 'net-zero emission buzzword' driven by governments, academics, corporations, investors and billionaires. As a "quasi-concept", social innovation addresses social change driven by everyday interactions, as well as the diverse ways in which social groups and communities deal with social, economic, and environmental challenges [26, 27]. Social innovation is applied to address global societal challenges, such as health and well-being [28], sustainable energy [29], and sustainable cities and communities [30].

Notably, civil society, the EV sector, financial institutions and local authorities must all play a crucial role in embracing socially innovative bottom-up approaches in engaging consumers and harnessing policy trade-offs and synergies in the transition to net-zero emission vehicles and futures. Having socially innovative business models with the right legislative frameworks will become valuable in the UK Green Industrial Revolution Plan to deliver the UN SDGs' and 2015 Paris Agreement's promises.

With Brexit's messy impact on the EV sector looming and EV global competitiveness at the heart of the UK Green Industrial Revolution Plan, new battery cell technological breakthroughs locally are imminent since sourcing battery raw minerals from within the UK or European Union (EU) will be the best way forward for the UK auto manufacturers to avoid EU tariffs from January 2024. Accordingly, investments in private battery companies, such as Britishvolt, with manufacturing, research and development capabilities are crucial to make the UK sustainable transport and renewable energy sector robust, competitive and resilient to meet domestic and global market needs. Also, new EV battery technological development and 2050 net-zero targets must ensure policies are in concert with solid-state batteries and a Gigafactory in the UK by 2023.

In fact, with the UK and EU countries banning fossil fuel vehicles and switching to EVs, the UK cannot become competitive unless it attempts to match companies such as General Motors in the US, seeking to overtake EV giants Tesla with a $\$ 27$ billion investment in the market and battery technology [31]. Chinese companies are also making considerable investments in EV start-ups, such as NIO (often referred to as the 'Tesla of China), which are experiencing soaring stock prices, improved battery range and swap model, with a more favourable policy environment to thrive [32, 33]. 


\section{Conclusions and future measures}

This paper explored responsible and circular business models useful for achieving equitable EV ownership and driving public policy goals towards net-zero emissions and sustainable futures.

As governments globally accelerate the ban and shift to net-zero emission vehicles, public policy measures and responsible business models must ensure the following:

(1) 'Leaving no one behind' by 2030 in the transition to EVs and addressing the myriad of economic, social, health and environmental injustices within low-income community households.

(2) A lower ULEV purchase price under innovative business models, e.g., through income taxes and manufacturers tax breaks, reduces the amount of upfront liquid assets required from low-income consumers.

(3) Consumers from low-income households and communities do not wait until 2030 to race to buy ULEVs. If ULEVs remain unaffordable to so many, then even if petrol/diesel car sales are banned in 2030, millions will still pollute the UK's roads for a decade(s) afterwards.

4) Business models and future work must integrate modularity circular economy designs into EV programs to stimulate net-zero emissions and a low-carbon grid.

(5) Accounting for upstream environmental pollution and carbon emissions impact within the EV and cleaner energy technologies global value chain, vis-à-vis the geographical unbundling economies', following the extraction, production, manufacturing, use and resource consumption patterns.

(6) New EV battery technological development and 2050 net-zero targets must ensure research and development policies are in concert with solid-state batteries and the development of at least a Gigafactory on the UK soil by 2023.

However it's done, net-zero emission vehicles policy goals must ensure 'no one is left behind'. Authorities and broader society have a moral obligation to accelerate EV ownership among low-income households and communities to address the socio-economic and environmental injustices of road traffic pollution and prevent thousands of deaths every year. Future net-zero emission decision-making and investments, including research, can help address value chain crosssectorial nexus impacts and SDGs' positive-sum outcomes that benefit the people, planet, prosperity and partnership.

Authors' contributions The author conceived the idea and wrote the brief communication. The author read and approved the final manuscript.

Declarations

Competing interests The author declares no competing interests.

Open Access This article is licensed under a Creative Commons Attribution 4.0 International License, which permits use, sharing, adaptation, distribution and reproduction in any medium or format, as long as you give appropriate credit to the original author(s) and the source, provide a link to the Creative Commons licence, and indicate if changes were made. The images or other third party material in this article are included in the article's Creative Commons licence, unless indicated otherwise in a credit line to the material. If material is not included in the article's Creative Commons licence and your intended use is not permitted by statutory regulation or exceeds the permitted use, you will need to obtain permission directly from the copyright holder. To view a copy of this licence, visit http://creativecommons.org/licenses/by/4.0/.

\section{References}

1. Bonsu N. Transition to Electric Vehicles: Stimulating Local Authorities to address charging infrastructure challenges. Policy Briefing. 2019. https://www.birmingham.ac.uk/Documents/research/Public-Affairs/Electric-Vehicles-final.pdf.

2. Electric car market statistics. https://www.nextgreencar.com/electric-cars/statistics/. Accessed 10 Nov 2020

3. Lyndhurst B. Uptake of Ultra Low Emission Vehicles in the UK, A Rapid Evidence Assessment for the Department for Transport. London: Department For Transport Brook Lyndhurst Ltd; 2015.

4. Air Quality News, 2019. Electric vehicles could save low-income households millions. https://airqualitynews.com/2019/11/14/electricvehicles-could-save-low-income-households-millions/. Accessed 10 Nov 2020

5. Marshall, C., 2018. Illegal levels of air pollution linked to child's death. https://www.bbc.co.uk/news/science-environment-44612642. Accessed 20 Nov 2020.

6. Mitchell G, Dorling D. An environmental justice analysis of British air quality. Environ Plan A. 2003;35(5):909-29. 
7. Barnes JH, Chatterton TJ, Longhurst JW. Emissions vs exposure: Increasing injustice from road traffic-related air pollution in the United Kingdom. Trans Res Part D. 2019;73:56-66.

8. Yang, Z., Slowik, P., Lutsey, N. and Searle, S., 2016. Principles for effective electric vehicle incentive design. International Council Clean Transportation June.

9. Bonsu NO. Towards a circular and low-carbon economy: Insights from the transitioning to electric vehicles and net-zero economy. J Clean Prod. 2020;256:120-659.

10. Nelson P, Santini D, Barnes J. Factors determining the manufacturing costs of lithium-ion batteries for PHEVs. World Electr Veh J. 2009;3(3):457.

11. Leyland A. Lithium-ion battery cell prices fall to $\$ 110 / \mathrm{kWh}$, but raw material risk looms large. Benchmark Mineral Intelligence. 2020. https://www.benchmarkminerals.com/membership/lithium-ion-battery-cell-prices-fall-to-110-kwh-but-raw-material-risk-looms-large -2/. Accessed 03 Jan 2021.

12. Stringer D, Park K., 2020. Why Building an Electric Car Is So Expensive, For Now. https://www.bloomberg.com/news/articles/2020-10-22/ why-building-an-electric-car-is-so-expensive-for-now-quicktake. Accessed 9 Jan 2020.

13. BU, 2020: BU-1003a: Battery Aging in an Electric Vehicle (EV). Battery University. https://batteryuniversity.com/learn/article/bu_1003a battery_aging_in_an_electric_vehicle_ev. Accessed 31 Jan 2020.

14. Warner NA. Secondary life of automotive lithium-ion batteries: an aging and economic analysis. Columbus: Doctoral dissertation. The Ohio State University; 2013.

15. Heymans C, Walker SB, Young SB, Fowler M. Economic analysis of second use electric vehicle batteries for residential energy storage and load-levelling. Energy Policy. 2014;71:22-30.

16. Saxena S, Le Floch C, MacDonald J, Moura S. Quantifying EV battery end-of-life through analysis of travel needs with vehicle powertrain models. J Power Sourc. 2015;282:265-76.

17. Sierzchula W, Bakker S, Maat K, van Wee B. The influence of financial incentives and other socio-economic factors on electric vehicle adoption. Energy Policy. 2014;68:183-94.

18. OLEV. Office for Low Emission Vehicles. Tax benefits for ultra-low emission vehicles. 2018. https://assets.publishing.service.gov.uk/gover nment/uploads/system/uploads/attachment_data/file/709655/ultra-low-emission-vehicles-tax-benefits.pdf. Accessed 31 Jan 2020.

19. APPTTUS. The ultimate guide to managing a subscription business. 2018. https://2wyzqu1t50vr2esar426fpzd-wpengine.netdna-ssl. com/thankyou/wpcontent/uploads/sites/19/2020/03/Apttus_Ultimate_Guide_to_Managing_a_Subscription_Business_2019_final.pdf. Accessed 5 Jan 2020.

20. Monhof, M., Beverungen, D., Klör, B. and Bräuer, S., 2015, May. Extending battery management systems for making informed decisions on battery reuse. In International Conference on Design Science Research in Information Systems (pp. 447-454). Springer, Cham.

21. Cready E, Lippert J, Pihl J, Weinstock I, Symons P 2003. Technical and Economic Feasibility of Applying Used EV Batteries in Stationary Applications (No. SAND2002-4084). Sandia National Labs, Albuquerque, NM (US). Sandia National Labs, Livermore, CA (US).

22. Hinson S, Bolton P. Fuel Poverty. Briefing Paper. Number 8730. House of Commons Library. 2020. https://commonslibrary.parliament.uk/ research-briefings/cbp-8730/. Accessed 6 Jan 2021.

23. World Bank, 2019. Climate-smart mining: minerals for climate action. Available at: http://www.worldbank.org/en/topic/extractiveindus tries/brief/climate-smart-miningminerals-for-climate-action. Accessed 1 Nov 2020.

24. UNEP. Environmental impacts of export of used vehicles to the developing world. 2020. https://www.unep.org/news-and-stories/press -release/new-un-report-details-environmental-impacts-export-used-vehicles. Accessed 12 Dec 2020.

25. CCC. Net Zero: Committee on Climate Change. The UK's Contribution to Stopping Global Warming. 2019. https://www.theccc.org.uk/ wp-content/uploads/2019/05/Net-Zero-The-UKs-contribution-to-stopping-global-warming.pdf. Accessed 4 Jan 2021.

26. Bonsu NO, TyreeHageman J, Kele J. Beyond agenda 2030: future-oriented mechanisms in localising the sustainable development goals (SDGs). Sustainability. 2020;12(23):9797.

27. Lukesch R, Ludvig A, Slee B, Weiss G, Živojinovi'c I. Social innovation, societal change, and the role of policies. Sustainability. $2020 ; 12: 7407$.

28. Currie WL, Seddon JJM. Social innovation in public health: can mobile technology make a difference? Inf Syst Manag. 2014;31:187-99.

29. Hiteva R, Sovacool B. Harnessing social innovation for energy justice: a business model perspective. Energy Policy. 2017;107:631-9.

30. Pultrone G. Urban regeneration as an opportunity of social innovation and creative planning in urban peripheries. TECHNE J Technol Archit Environ. 2017;14:139-46.

31. Ohnsman A. GM Sets Sights On Overtaking Tesla With $\$ 27$ Billion Push For EV Market Dominance. 2020. https://www.forbes.com/sites /alanohnsman/2020/11/19/gm-sets-sites-on-overtaking-tesla-with-27-billion-push-for-ev-market-dominance/?sh=7f1a8e012098. Accessed 20 Nov 2020.

32. NIO gets policy boost from the city where its China headquarters is based. Available at: https://cntechpost.com/2020/11/13/analystssay-nio-is-the-leading-chinese-ev-maker-with-advantages-becoming-apparent/. Accessed 24 Nov 2020.

33. Mullaney T. Chinese EV rivals line up to challenge Tesla on their home turf. 2020. https://www.cnbc.com/2020/11/23/chinese-ev-rival s-line-up-to-challenge-tesla-on-their-home-turf-.html. Accessed 25 Nov 2020.

Publisher's Note Springer Nature remains neutral with regard to jurisdictional claims in published maps and institutional affiliations. 